\title{
Spatial capital and planetary gentrification: residential location, mobility and social inequalities
}

\section{Patrick Rérat}

Final version to be published in Handbook of gentrification studies, 2018, Loretta Lees and Martin Philipps (eds.), Edgar Elgar Publishing, https://www.elgaronline.com/view/edcoll/9781785361739/9781785361739.xml

\section{$1.1 \quad$ INTRODUCTION}

Gentrification in its various forms is about place and more precisely place competition or place appropriation between classes. In this chapter I argue that the choice of a place of residence is a strategic decision that enables individuals or households to gain locational advantages that are crucial in negotiating and mastering the spatial aspects of everyday life. The term 'spatial capital' (see Rérat and Lees 2011; Rérat 2016) has been used to conceptualize these locational advantages, revealing them to be an additional form of classled appropriation of urban resources.

The conceptualisation of spatial capital allows for the opportunity to re-read gentrification through the lens of mobility. Mobility is at the core of multiple transformations of contemporary societies and of 'an intense phase of time-space compression that (has) had a disorienting and disruptive impact upon political-economic practices, the balance of class power, as well as cultural and social life' (Harvey 1989: 284). This increase in mobility pertains to all aspects of society playing out as a spatial rupture of the places of everyday life, flexibility as a requirement on the job market, the multiplication of ways of moving and their increase in speed, etc. (see Urry 2007).

In this chapter I read the gentrification studies literature using spatial capital as a guiding thread. I develop the concept of spatial capital by broadening the lens of analysis to the planetary scale (Lees, Shin, and López Morales 2016) referring to studies in a wide range of spatial, social, economic and institutional contexts. After a discussion of the concept of spatial capital, I present more precisely how residential location and mobility are involved in gentrification processes. I address spatial capital (1) as an element of social differentiation, and (2) as a source of inequality. 


\subsection{SPATIAL CAPITAL AS A THEORETICAL TOOL}

The notion of spatial capital as used here is mainly drawn from two authors: Jacques Lévy, a French geographer, who coined the term spatial capital in the 1990s, and Vincent Kaufmann, a Swiss sociologist, who developed the notion of motility ${ }^{1}$.

\subsubsection{Spatial capital}

Lévy defines spatial capital as the set of resources, accumulated by an actor, enabling her/him to engage with place and space, to profit, in accordance with her/his strategies, by the use of the spatial dimension of society (Lévy 2013: 147). The term capital refers to the work by Pierre Bourdieu. For him, individuals were not defined by social class but by the differing amounts of capital they possessed and their position in social space, which was made up of these different types of capital (Bourdieu 1984). He defined economic capital as financial assets and monetary income; cultural capital as an embodied disposition that reflects the habitus, it has two kinds - that incorporated through education and knowledge and the symbolic kind that demonstrates moral and aesthetic values; and social capital as that which is mobilized through social networks and relations. These different forms of capital are played out in the 'field', a kind of social arena in which Bourdieu recognizes the centrality of social relations to social analysis. Within a field the possession of capitals and the ability to deploy them allow an individual to gain social advantages.

Spatial capital is made up of the advantages brought by control over a series of geographic layouts in which scale is a determinant element (Lévy 2014: 48). It refers not only - or less - to the possibility of greater speed wrought by innovation in transport technologies (that enables travel across vast spaces) but more generally to the capacity to access quickly a certain type or a certain quantity of people or places (ibid.). Cities are spaces of multiple speeds and a high spatial capital means the utmost appropriation and articulation of the various scales and metrics (including the possibility to make use of pedestrian metrics).

Lévy (1994) distinguishes two components of spatial capital: position capital and situation capital. Position capital is related to a place and its spatial assets. It shows, notably, the importance of residential location in an urban region where space can be assimilated as a rare good and is an object of competition. Situation capital is related to an area, to a space appropriated by an individual through all kinds of mobility without abolishing distances but by mastering them. Mobility is one way to mitigate or compensate for a shortfall of position capital.

\footnotetext{
${ }^{1}$ Other scholars propose terms such as network capital (Urry 2007) or mobility capital (Murphy-Lejeune 2002) to show how the use of space may be an asset.
} 


\subsubsection{Motility}

Kaufmann for his part stressed the necessity of addressing the phenomenon of mobility beyond the actual practices of individuals and of taking into account their potential mobility (Kaufmann 2002). He developed the notion of motility and defined it as the way an individual or a group takes possession and utilizes the field of possibilities with regards to movement relative to his/her personal aspirations and projects. It encompasses three interdependent elements: access, competence and appropriation (Kaufmann, Bergman, and Joye 2004; Flamm and Kaufmann 2006).

First, access is related to the 'range of possible mobilities according to place, time and other contextual constraints, and may be constrained by options and conditions. The options refer to the entire range of means of transportation and communication available and the entire range of services and equipment accessible at a given time. The conditions refer to the accessibility of the options in terms of location-specific cost, logistics and other constraints' (Kaufmann, Bergman, and Joye 2004: 750). This 'personal access rights portfolio' (Flamm and Kaufmann 2006) is closely linked to the place where an individual lives. The availability of means of transport and communication makes some places more desirable than others within an urban region and more likely to be appropriated by a dominant class. Second, competence refers to the skills and abilities of individuals that are necessary to make use of the supply of means of transport and communication. Skills are multifaceted and can be physical (e.g. the ability to cycle), acquired (e.g. a driving licence) or organisational (e.g. the ability to plan and synchronize activities). Finally, appropriation refers to the strategies, motivations, values and practices of individuals. It includes the way individuals interpret and act upon access and competences (be they perceived or real) and how they use their potential mobilities.

A second notion goes hand in hand with motility: the territory's hosting potential. For Kaufmann (2011), every territory has a specific ability to accommodate the projects of individuals. It is made up of factors such as the available networks (roads, trains, airports, etc.) and their levels of performance, as well as the spatial structure both in terms of morphology and functions (density, size, labour market, diversity of services, etc.). Every action assumes that the environment offers opportunities for realizing that project (Gibson $2014)^{2}$. Consequently not all projects can be hosted anywhere: some areas are more able to cope with some projects, given their morphological characteristics, the laws that govern them, their accessibility, etc. (ibid.). The concept of (institutional) viscosity goes in the same direction; it was coined to balance the more agentive concept of motility with a theoretical

\footnotetext{
${ }^{2}$ Material artefacts are of utmost importance in a territory's potential. For example, the ability to live without a car, thanks to excellent public transport, helps to make such a way of life desirable and worth adopting (Kaufmann 2011).
} 
account of structural conditions and to capture the variable degrees of resistance or facilitation offered by a structural context (Doherty 2015). It can 'analytically distinguish settings and systems that enable and support mobility (low viscosity) from those that make it difficult or impossible (high viscosity), and express relational degrees between them (being more or less viscous)' (ibid. 254).

\subsubsection{Mobility as capital}

Several arguments for considering mobility as a capital have been put forward (for a more thorough discussion, notably with Bourdieu's work, see Lévy 1994, 2000; Kaufmann, Bergman, and Joye 2004; Kaufmann et al. 2015).

First, as for other forms of capital, an unequal level of spatial capital endowment characterizes different members of a society, reflecting the different degree of use, and mastery of, the spatial aspects of everyday life. In this sense, spatial capital is a factor in social differentiation. Individuals are not only endowed with varying degrees of mobility capital but also in different ways: "unlike cultural, social or economic assets, which refer to hierarchical position, motility refers to both the vertical and horizontal dimensions of social position, thus highlighting not only new forms of social inequality but also making it possible for us to distinguish between different lifestyles based on an individual's relationship to time and space' (Kaufmann 2011: 40) ${ }^{3}$.

Second, spatial capital can be accumulated and used for other social goods, it may be transformed into travel and it may be exchanged with other forms of capital. For example, a person could pay more money for their dwelling in order to benefit from what is perceived to be a more favourable location (locational advantage).

Third, spatial capital is not simply determined by the other forms of capital ${ }^{4}$. It depends on access, competence and appropriation that depend in turn on several variables such as residential location (availability of public transport, etc.), purchasing power (that enables the use of different means of transport, etc.), age (driving licence, etc.), awareness of environmental issues (in the choice to own a car, for example), mobility or migration experience, cognitive attitudes, and so on.

On the basis of the discussion of the theoretical framework of spatial capital the rest of the chapter analyzes how residential location and mobility are at play in gentrification.

\footnotetext{
${ }^{3}$ The same statement was made on spatial capital (Lévy 2000: 157).

${ }^{4}$ Critiques have, however, been raised on whether Bourdieu's work lacks a sufficient spatial dimension and whether spatial capital is an independent capital (see for example Lévy 2014; Kaufmann et al. 2015; Mace 2015).
} 


\subsection{SPATIAL CAPITAL AS AN ELEMENT OF SOCIAL DIFFERENTIATION}

\subsubsection{Spatial Capital and Gentrifiers' Residential Aspirations}

A part of the gentrification literature has focused on gentrifiers' housing choices. It has explored the residential motivations to live in a central area expressed by some part of the middle to upper classes in a situation where suburbanization has been dominant in EuroAmerican contexts. Authors have asked what makes gentrifiers ('urban seeking middle class') different from suburbanites ('urban fleeing') (Butler 1997)'?

The literature that has investigated why the central city became attractive for the 'new' middle classes has identified two logics or sets of motivations. The first one, the valorisation or distinction logic, is based on the urban way of life and on symbolic aspects such as conspicuous consumption, aesthetic values, and the rejection of suburbia as massproduced, standardized, and socially undifferentiated (e.g. Caulfield 1994; Ley 1996). In terms of Bourdieu's conceptual frame, these aspects could be gathered under the concept of cultural capital. Less present in the literature are the second range of motivations, practical and utilitarian logics, stressing the convenience of urban life and questions of proximity and accessibility.

In three case studies of new-build gentrification in Switzerland (Rérat and Lees 2011; Rérat 2012, 2016) we found that households moving to new central districts place location, proximity and mobility issues at the forefront of their motivations. The move allows them to acquire a specific spatial capital based on locational advantages and to capture advantages in both proximity and mobility. Living in a central area gives them an easy access to walking, cycling and urban public transport but also to the train system and its intercity connections ${ }^{6}$. The importance of these factors in the residential choices of these new-build gentrifiers indicates both the particular importance of spatial capital and their significant personal knowledge of the spatial capital of their chosen residential area. Their mobility patterns and practices show that they are both potentially hyper-mobile (they have accrued enough spatial capital to be very mobile, to use several means of transportation according to their needs) and hyper-fixed (they have strategically chosen particular fixed central city locations where they are locally rooted). They are 'mobile and rooted' and they move into dwellings, which they see as fixed points around which they organize their lifestyles.

Results on the importance of centrality, proximity and mobility have been found in several other contexts. The rediscovery of a place can generate a variety of spatial practices, such as in the Netherlands in reclaiming the streets as a living space by upper middle-class

\footnotetext{
${ }^{5}$ As discussed later, the distinction between suburbanization and gentrification is more and more blurred in many spatial contexts.

${ }^{6}$ Although the car is far from being absent, its role is reduced notably in comparison with those who reside in the suburbs.
} 
families (Karsten 2008). In London, Middleton (2008) found that walking played a key role in maintaining existing social relations and that walking made negotiating work, childcare and family life easier for gentrifiers. Hamnett and Whitelegg (2007) found that one-third of the gentrifiers they surveyed in Clerkenwell, London, said that their main residential motivation was the fact they could walk to their workplace. In Canadian cities, gentrifiers are characterized by a higher propensity to walk and to cycle to their workplace (Danyluk and Ley 2007; Barbonne 2008) and their everyday life rests upon proximity that is in opposition to the life in the suburbs. Research in Norway underlines the attractiveness of central locations to reduce commuting distances and the role of the car as well as to increase access to public services (Hjorthol and Bjornskau 2005).

Gentrification scholars have put forward several factors to interpret the importance of both mooring/fixity and mobility among the middle to upper class. A first interpretation refers to the expression of left-liberal political values and of environmental beliefs (Danyluk and Ley 2007), and of the rejection of the suburban way of life (Caulfield 1994), and of the fact that gentrifiers valorize 'liberation from motor transportation' (Hjorthol and Bjornskau 2005: 353). These "critical social practices" (Caulfield 1994) or counter-cultural values go against the automobile-dependant suburbs and the hegemony of automobility (Urry 2004) ${ }^{8}$. Such attitudes are even commodified by real estate developers as in the case of cycling in San Francisco (Stehlin 2015).

A more frequent interpretation - and non-exclusive - is that central locations help new middle-class households to combine work, social and family life. Such trend can be put in parallel with the increasing participation of women in the labour market (Bondi 1991) and the resulting growth in dual-career households or in relation to young urban parents (Karsten 2003). By contrast the suburbs are characterized as intrinsically patriarchal (Fishman 1987) with the time-space rhythms of separate spheres of work and daily life (Rose 1984) and automobile dependence (Newman and Kenworthy 1999). In the research on Swiss cities mentioned above, to live in a central area and to be able to reach other urban centres easily through rail connections is also a way to gain access and competence, and not always to be actually mobile but also as an insurance to be able to reach other labour markets (especially for young professionals at an early stage of their careers and in a context were work life is more fluid) (Rérat and Lees 2011). We find in these interpretations the idea of 'coping strategies' as identified by Butler and Robson (2003). By increasing their spatial capital these households reinforce their upper middle-class position and the interlinked patterns of mobility and fixity secure socio-spatial advantages.

\footnotetext{
${ }^{7}$ Critical social practices are efforts made by people to resist institutionalized patterns of dominance and create new conditions for their social activities (Caulfield 1994: xiii).

${ }^{8}$ They have, however, been predominantly observed in specific locations, such as the central areas of Western metropolises or in countries with a comparatively high modal share of alternatives to the car.
} 
The role and importance of proximity and mobility is however multifaceted. The mastery of spatial dimensions may imply strategies of selective social inclusion of the upper middle classes in the urban fabric. Andreotti et al. (2013) find, for example, that the upper middle classes in Milan, Madrid and Paris anchor themselves in their districts through the use of local infrastructures (leisure, consumption, etc.), and develop complex strategies of proximity and distancing with regard to other social groups. They therefore opt for 'partial exit' strategies, selecting the dimensions that they are willing to share with other social groups (especially in terms of their involvement in local community life). This ability to play with the double logic of participation/integration and disengagement/withdrawal (Hirschman 2004) constitutes another expression of spatial capital and shows the complex game of distance and proximity and its various meanings for gentrifiers.

This game is exemplified by the quality of schools which is of utmost importance for middle upper class if their aspirations are to be realized or relative privileges maintained

(Butler and Hamnett 2010). For Tonkiss (2013: 82):

'urban-seeking' gentrifiers who choose attractive locational positions in inner city neighbourhoods may prove to be 'urban-fleeing' when it comes to educational choices for their children. This means negotiating fixity and mobility in terms either of household relocations to the most desirable local catchments [...] or of daily out-migrations to more desirable schools $[\ldots]$.

Such households show a control over urban space where the ability to chose a neighbourhood as a place of residence (position capital) and/or the competence for mobility (situation capital) can be regarded as a resource in its own right (Barthon and Monfroy 2010).

These studies show that spatial capital is an element of social differentiation among the middle to upper classes. It helps to understand the diversity of residential choices among the middle to upper classes and the renewed attractiveness of central areas as a place of residence for parts of them. It highlights as well the importance of location and mobility in (enabling) certain lifestyles and the fact that central areas are not only places of urbanity, diversity, excitement, but also strategic locations. In that sense, these results runs counter to several ideas such as the hypothesis that transport and communication are annihilating the benefits of concentration (as advanced by the literature on urban decline) or that gentrification is becoming somewhat irrelevant in a context of generalized suburbanization (Keil 2013). 


\subsubsection{Spatial Capital and Gentrification: Moving Beyond Critical Social Practices}

There is a clear need to extend the scope of such studies beyond European and NorthAmerican contexts and to investigate further gentrifiers' spatial capital endowment as well as the uses and meanings of the duo mobility-fixity. This is even more relevant given two features of contemporary gentrification: the increasing diversity of gentrifiers and the increasing recognition of new geographies of gentrification both in terms of spaces and countries.

Gentrifiers' characteristics differ according to the form, the context, and the wave of gentrification. For Lees et al. (2016: 108), 'gentrifiers globally are [now] a much more diverse entity in terms of income (some are very rich, some lower-middle class), politics (some are liberal, some are conservative even authoritarian), and lifestyles (some are highly consumer-orientated, other much less so)'. Among them one group is of particular interest given the scope of this chapter: the highly mobile transnational class. Donzelot (2004) argues that gentrifiers are characterized by a certain degree of ubiquity. He asserts that they valorize proximity and its advantages, but as members of a global elite also want to be elsewhere on the globe quickly and easily through either real or virtual networks. This is the case of, for example, super-gentrifiers in London for whom both local face-to-face communication and global presence were important (Butler and Lees 2006).

This echoes several empirical observations on transnational gentrification such as in Panama where redevelopment capital is local but the demand does not come from a single city-region but is transnational (Sigler and Wachsmuth 2016). Another compelling example of the tension between 'global wealth migration and local affordability' (Stiem 2016) is Vancouver. The globalisation of the city's real estate market - due to the flood of foreign capital, mainly from China - has significantly driven the rise of housing prices. Housing prices have decoupled from the regional labour market, putting people employed locally at a major disadvantage'. 'Millionaire migrants' continue their professional activities and to build their fortune in China while their families settle in Vancouver (for various reasons such as the quality of life, children's education, geopolitical issues, etc.) (Ley 2010: 77). These 'astronaut families' display a specific and high spatial capital endowment that enables a way of life spread on two continents, that mitigates the effects of distance, and that is notably based on airline connections. Such a spatial capital greatly varies from the quest for proximity and the critical social practices discussed above.

\footnotetext{
${ }^{9}$ Beyond the case of Vancouver, similar trends can also be observed in many contexts where tourism or secondhomes act as drivers of gentrification. The same phenomenon happens for example in London where an inflated property market has been blamed on overseas investors such as Middle-Eastern oil wealth or Russian elites/oligarchs (Lees et al. 2016: 110).
} 
Another point is the call made by several authors for a broader 'geography of gentrification' in order to take into account the contextuality of the phenomenon (Lees 2000). Two elements seem particularly relevant here: the spaces of gentrification in the global North and the specificities of cities/contexts in the global South. Regarding spaces of gentrification in the global North, the literature has extended the definition of 'gentrification' to encompass other spaces such as rural gentrification (Smith and Phillips 2001). At the same time, the distinction between gentrification and suburbanization has become less salient. For Lees et al. (2016: 211), 'planetary gentrification is not a reaction against suburbanization: indeed the two processes are increasingly blurred, as they are in the global North now too'. Case studies in New York and London, for example, have highlighted the suburban mindsets of supergentrifiers (Lees 2003; Butler and Lees 2006). Less is known on the specific spatial capital of the households involved in forms and spaces other than in classic inner-city gentrification.

In the global South, greater attention is needed to gentrification processes where gentrifiers' spatial capital and housing choices are likely to differ from those observed in European and North-American case studies. A first difference is the definition of the 'new' middle class ${ }^{10}$, its origin, its lifestyles, etc. In the global South, 'the term "new" middle class [...] refers to a newly emerging or expanding, modernizing middle class with new spending power and associated interest in consumerism' (Lees, Shin, and López Morales 2016: 83). These gentrifiers are not the same as the classic gentrifiers in the Euro-American context. When considering gentrification in the global South, 'the Western, consumption thesis and the idea of gentrification as a counter-cultural idea posited against the modern suburbs has no traction' (ibid. 96). By the same token 'with no experience of the post-war hegemony of suburban life, gentrifiers outside of Western cities will undoubtedly have different mindsets' (ibid.). Even though some authors show the similarities with what has been observed in the North (see for example, Contreras Gatica 2011, on gentrification in Santiago de Chile), others underline the importance of economic capital and peoples' desire to accumulate wealth by investing in real estate properties as in the case of Hong Kong (Ley and Teo 2014) or Chinese cities (Ren 2008). In some cities, gentrification is also closely related to gated communities (Alvarez-Rivadulla 2007), which in the words of Hirschmann (2004) means a clear exit from parts of the city. This elite withdrawal can also be termed as 'separatism' or 'secession', takes various built forms (from secured buildings to fortified enclaves), and is motivated by security concerns and by the 'discourse of urban fear' (Low 2001).

Spatial capital appears to be useful in analysing how privileged groups employ urban spaces, in combination with mobility, in ways which produce inequitable opportunities. More in-depth work on gentrifiers' motivations, spatial capital and lifestyles is crucially needed, all the more so in Southern cites which generally differ from their Northern counterparts in

\footnotetext{
${ }^{10}$ It has to be noted that important differences exist as well within the Global North. The term 'middle class' does not have the same meaning in English and in French for example (the English 'middle class' would be the middle to upper/high class in a French-speaking context).
} 
terms of urban form, population size, demographic dynamics, inequalities among classes, service and infrastructure provision, modal shares and state direction.

\subsection{SPATIAL CAPITAL AS A SOURCE OF INEQUALITY}

\subsubsection{Spatial Capital and Evicted Populations}

For gentrifiers the creation of spatial capital may be the result of strategies and residential choices. Gentrification may also lead to a contraction or destruction of spatial capital among the evicted populations, generating an additional source of inequality (Rérat and Lees 2011).

The eviction of lower income groups is a multifaceted process (Atkinson 2000; Davidson and Lees 2005; Davidson 2008). The most obvious form of eviction is direct displacement. Other forms include indirect economic displacement ('price shadowing'; inflation in land and property values in surrounding areas), community displacement (changes in neighbourhood governance and place identity), and neighbourhood resource displacement (transformation in the orientation of neighbourhood services and an increasing 'out-of-placeness'). Displacement goes beyond physical displacement and involves phenomenological displacement and loss of sense of place (Davidson 2008).

In addition to the loss of their neighbourhood (and therefore of social capital) through gentrification, displacement can also result in a reduction of spatial capital. Few studies have directly addressed this issue despite its importance. Two studies in Shanghai for example showed that the dislocation of displacees from urban amenities and services is socially unjust and problematic. Evicted residents interviewed by Ren (2008: 39) summed up well the impact of displacement on spatial capital and on the access to services ('I don't want to live in the suburbs. There are no hospitals. It takes hours to get to the city and see a doctor by bus') and to job opportunities ('I can still make a living here in the city centre [...]. What can I do in the suburbs?'). Similarly, He (2010) shows that the residents evicted to the fringes of Shanghai were unable to commute from their new place of residence. With their displacement came the destruction of some important parts of their spatial capital. Their previous location was a guarantee to have access to many nearby amenities and work opportunities. The new peripheral location made them dependent on other forms of transportation that might be too expensive and not practical or quick enough.

These results raise the question of the importance of access and mobility. As said by Brand and Dávila (2011: 649), 'limited mobility constrains participation in urban life in general, and opportunities to expand work horizons, social and leisure activities, political and civic engagement. Lack of mobility turns geographical marginalisation into deeper social exclusion'. Peripheral locations may deepen the spatial mismatch between affordable neighbourhoods and available job opportunities. It limits people's ability to travel by foot and 
the high costs of public transport restrict people's movement to the strictly essential, as Ureta (2008) analyzed in Santiago, Chile.

More generally, as Lees et al. (2016: 76) argue, 'what the concept of spatial capital can inform us of is an understanding of what differentiates the gentrifiers from the gentrified is not only their economic power to purchase, assemble and/or speculate with land and properties, but also, crucially, their class differentiated material and immaterial accumulation of access to a wider range of spatial capital'. The displacement of low-income groups may involve a more difficult access to urban amenities and job opportunities. The new residential location may require a higher economic capital (e.g. the purchase of a car or of public transport tickets) or new skills (e.g. driving licence) and it may be characterized by a lower territory's hosting potential ${ }^{11}$. More studies are needed on displacement and on the ways displaced populations (have to) cope with the loss of spatial capital (strategies, tactics of resistance, adaptation, etc.).

\subsubsection{Spatial Capital as an Uneven Impact of Transport Infrastructures}

A further dimension of spatial capital in the gentrification literature is the uneven impacts of new transport infrastructure on spatial capital endowment among classes. As stated by Revington (2015: 1), 'relatively little work has considered how transportation systems may impact social equity through land use changes, particularly gentrification'. Public transit is widely thought of as a means of promoting social equity and it can make a real difference to isolated or deprived neighbourhoods. But 'if neighbourhoods receiving new transit infrastructures gentrify, social equity will be undermined on two fronts: as existing residents endure housing affordability problems or are displaced, and as the mobility benefits of the new infrastructures fail to reach those it displaces' (ibid.).

The gentrification literature raises more generally the question of who benefits and who does not from transportation policies and infrastructures, or, to use the concept that frames this chapter, who is able to benefit from the generation of spatial capital. Indeed transport-oriented policies transform spatial opportunities in the city and they may (explicitly or not) be aimed at upper-income social groups (Blanco, Bosoer, and Apaolaza 2014). In other words, policy-led changes in transport access may allow one class to increase their chances of taking over a certain territory while the other class loses access to it (Lees, Shin, and López Morales 2016: 76).

The construction of transport infrastructures may be the catalyst for spatial restructuring and lead to the displacement of lower income groups (as discussed earlier in terms of general displacement whatever its cause, be it residential, commercial or infrastructural development). An obvious form of development-led displacement is direct

\footnotetext{
${ }^{11}$ It could be said that such a move is for the middle-class suburbanites more a choice of lifestyle and residential aspirations. It also involves mobility practices that they need to master or be ready to adopt.
} 
displacement, which refers to the eviction of a population to build a transport infrastructure. In Brussels, for example, the extension of a station for high-speed trains, which was part of the Brussels International Development Plan, was a type of adaptation of urban spaces for globalization and led to the de-structuration of a popular neighbourhood (Van Criekingen 2008).

New infrastructures generate not only direct but also indirect displacement. Public transportation projects, the increased level of accessibility and planning policies may enlarge rent gaps, valorize the land surrounding the infrastructure, lead to skyrocketing property values, and increase displacement pressures. They may create locational advantages that attract gentrifiers and provide them with practical and convenient access to mobility options and eventually to urban amenities and services.

Such impacts echo a characteristic of gentrification in the global South: 'its widespread occurrence after the creation of new centralities in previously undervalued urban areas, but whose location has become strategic [...] for higher-status office or residential revitalization, or service provision' (Lees, Shin, and López Morales 2016: 75), which results in the 'neo-Haussmannization [...] that has peripheralized millions of people everywhere' (Lees, Shin, and López-Morales 2015: 443). In Santiago de Chile for example, the metro enlarged rent gaps and enabled new social classes to capture spatial capital (López-Morales 2010). Investments in transport infrastructures have also been reported to go along with the formalization of settlements or slums. In Mexico City, huge investments in transportation facilities were followed by the rezoning of vast areas that displaced low-income tenants and petty landowners from already formalized, yet highly underserviced, land, where they had lived for more than 30 years (Delgadillo 2016). In Manila, a metropolitan rail project lead to the removal of informal settlements and the formalization of the land use, thereby opening the door to formal development (Choi 2016); while in Rio de Janeiro the whole redevelopment process in the city is underpinned by transport-oriented public investment penetrating the most emblematic favelas (Cummings 2015).

Another form of displacement (through housing price increase) may happen after the closing down of a transport infrastructure, the physical 'beautification' of areas and the creation of new urban amenities. In Seoul, the Cheonggye Stream had been buried to make room for an urban elevated highway in accordance with modernist planning principles. Its restoration in the 2000s induced an increase in land values in surrounding areas and 'accelerated land use change as land owners [sought] to maximize profits by attracting more affluent users who value[d] the newly created urban open space' (Lim et al. 2013: 199) ${ }^{12}$. In Zurich, the Weststrasse ('West Street') was used as a transit route by a huge number of trucks between two highways and crossed a residential neighbourhood. The noise, pollution, filth

\footnotetext{
${ }^{12}$ A similar process was observed in New York where a decaying railroad viaduct was redeveloped to a celebrated public park: the High Line (Loughran 2014).
} 
and dangers caused by the motorized traffic meant very low rents that attracted a workingclass population $^{13}$. The construction of a new highway released the traffic from Weststrasse and investment was targeted at the improvement of public space. Houses were soon refurbished and rents increased triggering a quick turnaround of residents as documented by a eight-year photography report (Flühmann 2015). This raises a more global issue of whether liveability is a transformative use-value akin to the "right to the city" (Lefebvre, Kofman and Lebas 1996) or an "amenity that adds to exchange-value in space" (Stehlin 2015: 133).

In the examples discussed above, the mechanism of gentrification refers to the access dimension of spatial capital. There is a competition for space and for a location that enables the use of certain transportation means (but without suffering from the nuisances of transportation itself). In market economies this competition is expressed in land and housing prices and leads to the direct or indirect eviction of households with low economic capital to a location, in all likelihood, with a lower level of access (and with a lower hosting potential/higher viscosity).

Other mechanisms can be identified with respect to the uneven impact of transport infrastructures. In several US cities, protests have targeted corporate shuttles, such as in San Francisco with Google Buses. This figure of speech designs the luxury buses networks that are privately chartered and that transport 35,000 employees of the technological companies from San Francisco to the Silicon Valley. Although being private these 'tech shuttles' use public bus stops to pick up tech employees 'using public money for private gains' and they even cause the deterioration if the public transit service (McCleave Maharawal 2014). This example shows - to use Doherty's metaphor (2015) - a differentiated impact on viscosity of urban space (higher for public transit users, lower for tech employees). It is also another dimension of the uneven endowment of spatial capital in the same territory due to the exclusion from (or denial of access to) a private service in a context of low public transit supply.

The uneven impact of transport infrastructure does not only rely on economic capital, location and access but also on the other dimensions of spatial capital. Brand and Dávil (2011) analyzed the Metrocable (aerial cable-car system) that was built in dense and hilly low-income informal settlements in Medellín, Colombia. The access factor is not really important (its cost was quite low even in comparison with alternatives such as buses) but appropriation was crucial. The Metrocable provides an infrastructural articulation of formal urban life and the main group of users is comprised of formal sector workers with long journey to work patterns. For social groups outside formal networks or whose everyday routines are circumscribed within the locality, the level of appropriation is much lower.

\footnotetext{
${ }^{13}$ While the construction of transport infrastructures or improvements may lead to gentrification, existing infrastructure may also produce nuisances, lower the quality of life and raise important issues in terms of environmental vulnerability and social justice.
} 
Another example is provided by the links between bicycle infrastructures and gentrification with a literature mainly based in the United States where the modal share of bikes in commuting trips $(0.6 \%)$ is very low by international standards (Pucher and Buehler 2012; McKenzie 2014). In American cities such as San Francisco, cycling and bike schemes have become seen as forerunners of gentrification or synonymous with well-off white men. It is interesting to read this debate through the lens of spatial capital/motility. Access or skills do not seem to be the most important issue. US census data (McKenzie 2014) actually shows that bike use is negatively correlated with income (e.g. low-income commuters are the most likely to bike, which put things into perspective on a national scale). The access to bike infrastructure is free to use and bikes are not expensive in comparison with other modes of transportation (except walking). The differences are mainly to be found in appropriation and the territory's hosting potential.

In terms of appropriation, cars and bikes convey different values, particularly among generations and social classes that may promote/hinder some mobility practices. The car has long been - and still is, at least partly - regarded as an important symbol of success and social status (Urry 2004), while bikes have long been the vehicle of the working classes for most of the 20th century ${ }^{14}$. Cycling nowadays has various meanings and images. A car-free identity may be countercultural and an embodied critique of decades of sprawl and car dependence (Horton 2006). It can also be seen as a practice of another race or class (either the elite who are able to chose to live more localized patterns of mobility; or the poorest who do not have a choice), as the calling into question of a social status symbol, as a threat to a way of life and as the start of neighbourhood change.

In terms of territorial hosting potential (cyclability or bikeability as it happens), bike infrastructures point to much deeper inequalities in American cities. For Stehlin (2015: 124), 'the real gains in bicycle space in select areas of core cities must be seen in the context of a vast, intensely car-dependent region in which the possibility of replacing the car trips by bicycle or mass transit is supremely uneven in distribution'. Urban structure and the degree of suburbanization of jobs, population and classes are indeed of utmost importance. Bike infrastructures are associated with unequal public resources, privilege and change (most of all when bike lanes appear when new people move in) but also with the symbolic appropriation of local space.

Spatial capital can be used to analyze the links between transport infrastructures and gentrification either through development-led displacement (direct or indirect), the way agencies plan infrastructures and their uneven impacts. This analytical framework highlights the various dimensions where inequalities may be at work. More research could be done to evaluate the impacts of transport infrastructures on housing prices and on the populations living in the adjacent areas (in terms of mobility practices, participation in the labour market,

\footnotetext{
${ }^{14}$ When it was invented in the 19th century, the bicycle was first for the leisure of the bourgeoisie.
} 
etc.). Moreover the research identified in this chapter deals mainly with transit, cycling and walking as sources of inequality. The dominant or hegemonic system of automobility and the many impacts of automobile dependence (in terms of social inequalities, externalities, environmental justice, household budget, etc.) (Newman and Kenworthy 1999; Urry 2004; Dennis and Urry 2009) have all but disappeared in Euro-America and should receive more attention.

\subsection{CONCLUSION}

Gentrification is a multi-faceted phenomenon. As it involves a form of class-led appropriation of urban resources, I argue that spatial capital can be a useful tool to analyze some of its mechanisms and impacts. Spatial capital refers to mastery or command over space, the ability to make profit from the spatial dimension of society, to make spatial choices in terms of both fixed location and mobilities, to organize one's life according to aspirations and constraints (Lévy 2014). This has also been expressed with the notion of motility which highlights three dimensions related to individuals: access (range of possible mobilities according to place and time), competence (physical, acquired, organisational) and appropriation (strategies, motivations, values) (Kaufmann, Bergman, and Joye 2004). The notion of a territory's hosting potential (Kaufmann 2011) or (institutional) viscosity (Doherty 2015) take into account more structural elements. Class inequalities may turn on access, competence, appropriation of (new) mobilities and urban space itself, which that can be an object of political struggle.

In this chapter, this analytical grid has been applied to gentrification to highlight how spatial capital is an element of social differentiation. It contributes to explain why central areas in the global North have become attractive for the 'new' middle class. Gentrifiers with a strategic move acquire a specific capital and are able to capture the advantages of both proximity/mooring and mobility (Rérat and Lees 2011). Their mastery of space, and their management of proximity and mobility, represent a complex strategy of participation/integration and disengagement/withdrawal with regard to other social groups (Andreotti, Le Galès, and Javier Moreno Fuentes 2013). However, gentrifiers have become a much more diverse entity and gentrification has taken place in other spatial contexts than the inner cities in the global North (Lees, Shin, and López-Morales 2015). Further analysis of gentrification using the lens of spatial capital across a wider range of forms, spaces and countries is crucially needed.

The chapter has also discussed spatial capital as a source of inequality. Gentrification may lead to a contraction of spatial capital among the evicted population, to the loss of the resources enabling them to use the spatial dimension of society (e.g. access to job opportunities, services, urban amenities, etc.). An additional dimension is the uneven impacts of new transport infrastructures among classes (e.g. direct or indirect displacement, denied 
access to transport due to the level of prices, lack of skills or appropriation, etc.). Here again studies are needed on the ways displaced populations cope with the loss of their spatial capital, the strategies or tactics of resistance they adopt and the mechanisms behind the uneven impacts of transport infrastructures.

The issues raised in this chapter are crucial in the debates on urban planning in a context characterized by the domination of the market, the withdrawal of the state and a higher than ever demand for well-positioned urban space. Gentrification raises the question of social justice in urban development, of the right to the city that implies the equal access to housing, land, social rights and urban amenities and commodities. Moreover mobility practices are not only at the core of the functioning of societies but will be facing fundamental changes (Dennis and Urry 2009): global warming and oil depletion will require the transition to a low-carbon mobility and the diffusion of the autonomous car will have a disruptive and uneven impact on the way mobility is organized and practised in cities. The concept of spatial capital could be used as an analytical grid but also as a tool for planning practice (Mace 2015). By deconstructing the mechanisms behind the uneven use of the spatial dimensions of society, it could help to analyze how households are/are not able to exploit proximity and to use transportation supply. It could also help to evaluate the impact of transport infrastructures in respect to the needs of the various population groups in order to find ways to envision an urban development capable of integrating spatial justice.

\section{REFERENCES}

Alvarez-Rivadulla, M.J. (2007), 'Golden ghettos: gated communities and class residential segregation in Montevideo, Uruguay', Environment and Planning A, 39 (1), 47-63.

Andreotti, A., P. Le Galès, and Javier Moreno Fuentes, F. (2013), 'Controlling the urban fabric: the complex game of distance and proximity in European upper-middle class residential strategies', International Journal of Urban and Regional Research, 37 (2), $576-597$.

Ascher, F. (1995), Métapolis ou l'avenir des villes, Paris: Odile Jacob.

Atkinson, R. (2000), 'Measuring gentrification and displacement in Greater London', Urban Studies, 37 (1), 149-165.

Barbonne, R. (2008), 'Gentrification, nouvel urbanisme et évolution de la mobilité quotidienne : vers un développement plus durable? Le cas du Plateau Mont-Royal (19982003)', Recherches sociographiques, 49 (3), 423.

Barthon, C. and Monfroy, B. (2010), 'Sociospatial schooling practices: a spatial capital approach', Educational Research and Evaluation, 16 (2), 177-196. 
Blanco, J., Bosoer, L. and Apaolaza, R. (2014), 'Gentrificación, movilidad y transporte: aproximaciones conceptuales y ejes de indagación', Revista de geografia Norte Grande, (58), 41-53.

Bondi, L. (1991), 'Gender divisions and gentrification: a critique', Transactions of the Institute of British Geographers, 16 (2), 190-198.

Bourdieu, P. (1984), Distinction: A Social Critique of the Judgement of Taste, Cambridge, MA.: Harvard University Press.

Brand, P., and Dávila, J.D. (2011), 'Mobility innovation at the urban margins: Medellín's metrocables', City, 15 (6), 647-661.

Butler, T. (1997), Gentrification and the Middle Classes, Aldershot: Ashgate.

Butler, T. and Hamnett, C. (2010), "You take what you are given": the limits to parental choice in education in east London', Environment and Planning A, 42 (10), 2431-2450.

Butler, T. and Lees, L. (2006), 'Super-gentrification in Barnsbury, London: globalisation and gentrifying global elites at the neighbourhood level', Transactions of the Institute of British Geographers, 31, 467-487.

Caulfield, J. (1994), City Form and Everyday Life: Toronto's Gentrification and Critical Social Practice, Toronto: University of Toronto Press.

Choi, N. (2016), 'Metro Manila through the gentrification lens: disparities in urban planning and displacement risks', Urban Studies, 53 (3), 577-592.

Contreras Gatica, Y. (2011), 'La recuperación urbana y residencial del centro de Santiago: Nuevos habitantes, cambios socioespaciales significativos', EURE (Santiago), 37 (112), 89-113.

Cummings, J. (2015), 'Confronting favela chic: the gentrification of informal settlements in Rio de Janeiro, Brazil', in L. Lees, H.B. Shin, and E. López-Morales (eds.), Global Gentrifications, Policy Press, 81-100. [Online] Available at: http://policypress.universitypressscholarship.com/view/10.1332/policypress/97814473134 72.001.0001/upso-9781447313472-chapter-5 (accessed 14 July 2016).

Danyluk, M. and Ley, D. (2007), 'Modalities of the new middle class: ideology and behavior in the journey to work from gentrified neighbourhoods in Canada', Urban Studies, 44 (11), 2195-2210.

Davidson, M. (2008), 'Spoiled mixture - where does state-led “positive” gentrification end?', Urban Studies, 45 (12), 2385-2405.

Davidson, M. and Lees, L. (2005), 'New-build "gentrification" and London's riverside renaissance', Environment and Planning A, 37, 1165-1190. 
Delgadillo, V. (2016), 'Selective modernization of Mexico City and its historic center. Gentrification without displacement?', Urban Geography, 1-21.

Dennis, K. and Urry, J. (2009), After the Car, Cambridge; Malden, Mass.: Polity Press.

Doherty, C. (2015), 'Agentive motility meets structural viscosity: Australian families relocating in educational markets', Mobilities, 10 (2), 249-266.

Donzelot, J. (2004), 'La ville à trois vitesses: relégation, périurbanisation, gentrification', Esprit, 303, 14-39.

Fishman, R. (1987), Bourgeois Utopias: The Rise and Fall of Suburbia, New York: Basic Books.

Flamm, M. and Kaufmann, V. (2006), 'Operationalising the concept of motility: a qualitative study', Mobilities, 1 (2), 167-189.

Flühmann, C. (2015), Weststrasse, Zürich: Edition Frey.

Gibson, J.J. (2014), The Ecological Approach to Visual Perception, Hoboken: Taylor \& Francis.

Hamnett, C. and Whitelegg, D. (2007), 'Loft conversion and gentrification in London: from industrial to postindustrial use', Environment and Planning A, 39, 106-124.

Harvey, D. (1989), The Conditions of Postmodernity, Oxford: Blackwell.

He, S. (2010), 'New-build gentrification in central Shanghai: demographic changes and socioeconomic implications', Population, Space and Place, 16 (5), 345-361.

Hirschman, A.O. (2004), Exit, Voice, and Loyalty: Responses to Decline in Firms, Organizations, and States, Cambridge, Mass: Harvard University Press.

Horton, D. (2006), 'Environmentalism and the bicycle', Environmental Politics, 15 (1), 4158.

Karsten, L. (2003), 'Family gentrifiers: challenging the city as a place simultaneously to build a career and raise children', Urban Studies, 40 (12), 2573-2584.

Karsten, L. (2007), 'Housing as a way of life: towards an understanding of middle-class families' preference for an urban residential location', Housing Studies, 22 (1), 83-98.

Karsten, L. (2008), 'The upgrading of the sidewalk: from traditional working-class colonisation to the squatting practices of urban middle-class families', Urban Design International, 13, 61-66.

Kaufmann, V. (2002), Re-thinking Mobility: Contemporary Sociology, Aldershot: Ashgate.

Kaufmann, V. (2011), Rethinking the City: Urban Dynamics and Motility 1st ed, Milton Park, Abingdon, Oxon; New York, NY.; Lausanne, Switzerland: Routledge; EPFL Press. 
Kaufmann, V., Bergman, M.M. and Joye, D. (2004), 'Motility: mobility as capital', International Journal of Urban and Regional Research, 28 (4), 745-756.

Kaufmann, V., Ravalet, E., Dupuit, E. and S. Ecole polytechnique fédérale Lausanne (eds.) (2015), Motilité et mobilité: mode d'emploi, Neuchâtel: Éditions Alphil-Presses universitaires suisses.

Keil, R. (ed.) (2013), Suburban Constellations: Governance, Land and Infrastructure in the 21st Century, Berlin: Jovis Verlag.

Lees, L. (2000), 'A re-appraisal of gentrification: towards a geography of gentrification', Progress in Human Geography, 24, 398-408.

Lees, L. (2003), 'Super-gentrification: the case of Brooklyn Heights, New York City', Urban Studies, 40 (12), 2487-2500.

Lees, L., Shin, H.B. and López-Morales, E. (eds.) (2015), Global Gentrifications: Uneven Development and Displacement, Bristol, UK; Chicago, IL.: Policy Press.

Lees, L., Shin, H.B. and López Morales, E. (2016), Planetary Gentrification, Cambridge, UK: Malden, MA.: Polity Press.

Lefebvre, H., Kofman, E. and Lebas, E. (1996), Writings on Cities, Cambridge, Mass, USA: Blackwell Publishers.

Lévy, J. (1994), L'espace légitime: sur la dimension géographique de la fonction politique, Paris: Presses de la Fondation nationale des sciences politiques.

Lévy, J. (2000), 'Les nouveaux espaces de la mobilité', in M. Bonnet and D. Desjeux (eds.), Les territoires de la mobilité, Paris: Presses universitaires de France, 155-170.

Lévy, J. (2013), 'Capital spatial', in Dictionnaire de la géographie et de l'espace des sociétés, Paris: Belin, 147-149.

Lévy, J. (2014), 'Inhabiting', in R. Lee (ed.), The Sage Handbook of Human Geography, Thousand Oaks, CA.: SAGE Publications Ltd, 45-68.

Ley, D. (1996), The New Middle Class and the Remaking of the Central City, Oxford: Oxford University Press.

Ley, D. (2010), Millionaire Migrants. Trans-Pacific Life Lines, London: Wiley-Blackwell.

Ley, D. and Teo, S.Y. (2014), 'Gentrification in Hong Kong? Epistemology vs. Ontology', International Journal of Urban and Regional Research, 38 (4), 1286-1303.

Lim, H., Kim, J., Potter, C. and Bae, W. (2013), 'Urban regeneration and gentrification: land use impacts of the Cheonggye Stream Restoration Project on the Seoul's central business district', Habitat International, 39, 192-200. 
López-Morales, E. (2010), 'Real estate market, state-entrepreneurialism and urban policy in the "gentrification by ground rent dispossession" of Santiago de Chile', Journal of Latin American Geography, 9 (1), 145-173.

Loughran, K. (2014), 'Parks for profit: the high line, growth machines, and the uneven development of urban public spaces', City \& Community, 13 (1), 49-68.

Low, S.M. (2001), 'The edge and the center: gated communities and the discourse of urban fear', American Anthropologist, 103 (1), 45-58.

Mace, A. (2015), 'Spatial capital as a tool for planning practice', Planning Theory: 1-14.

McCleave Maharawal, M. (2014), 'Protest of gentrification and eviction technologies in San Francisco', Progressive Planning, 199, 20-24.

McKenzie, B. (2014), 'Modes less traveled - bicycling and walking to work in the United States: 2008-2012', American Community Survey Reports, 25, 1-18.

Middleton, J. (2008), 'London: the walkable city', in R. Imrie, L. Lees and M. Raco (eds.), Regenerating London: Governance, Sustainability and Community in a Global City, London: Routledge, 174-192.

Murphy-Lejeune, E. (2002), Student Mobility and Narrative in Europe: The New Strangers, London; New York: Routledge.

Newman, P. and Kenworthy, J. (1999), Sustainability and Cities: Overcoming Automobile Dependence, Washington: Island Press.

Pucher, J. R. and Buehler, R. (eds.) (2012), City Cycling, Cambridge, Mass.: MIT Press.

Ren, X. (2008), 'Forward to the past: historical preservation in globalizing Shanghai', City \& Community, 7 (1), 23-43.

Rérat, P. (2016), 'Motivations résidentielles et pratiques de mobilité des classes moyennes supérieures dans les villes suisses', Espaces et sociétés, 164-165 (1), 159-178.

Rérat, P. (2012), 'Gentrifiers and their choice of housing: characteristics of the households living in new developments in Swiss cities', Environment and Planning A, 44 (1), 221236.

Rérat, P. and Lees, L. (2011), 'Spatial capital, gentrification and mobility: evidence from Swiss core cities', Transactions of the Institute of British Geographers, 36 (1), 126-142.

Revington, N. (2015), 'Gentrification, Transit, and Land Use: Moving Beyond Neoclassical Theory', Geography Compass, 9 (3), 152-163.

Rose, D. (1984), 'Rethinking gentrification: beyond the uneven development of Marxist urban theory', Environment and Planning D, 1, 47-74. 
Sigler, T. and Wachsmuth, D. (2016), 'Transnational gentrification: globalisation and neighbourhood change in Panama's Casco Antiguo', Urban Studies, 53 (4), 705-722.

Smith, D.P. and Phillips, D.A. (2001), 'Socio-cultural representations of greentrified Pennine rurality', Journal of Rural Studies, 17 (4), 457-469.

Stehlin, J. (2015), 'Cycles of investment: bicycle infrastructure, gentrification, and the restructuring of the San Francisco Bay Area', Environment and Planning A, 47 (1), 121137.

Stiem, T. (2016), 'Race and real estate: how hot Chinese money is making Vancouver unlivable', The Guardian. [Online] Available at: https://www.theguardian.com/cities/2016/jul/07/vancouver-chinese-city-racism-meetsreal-estate-british-columbia?CMP=share_btn_tw.

Tonkiss, F. (2013), Cities By Design: The Social Life of Urban Form, Cambridge: Polity Press.

Ureta, S. (2008), 'To move or not to move? social exclusion, accessibility and daily mobility among the low-income population in Santiago, Chile', Mobilities, 3 (2), 269-289.

Urry, J. (2004), 'The “system” of automobility', Theory, Culture \& Society, 21 (4-5), 25-39.

Urry, J. (2007), Mobilities, Cambridge: Polity.

Van Criekingen, M. (2008), 'Urbanisme néolibéral et politiques de gentrification: main basse sur le quartier de la gare TGV à Bruxelles', Géo-Regards, 1, 113-125.

Visser, G. and Kotze, N. (2008), 'The state and new-build gentrification in central Cape Town, South Africa', Urban Studies, 45 (12), 2565-2593. 